\title{
Advancing stem cell therapy from bench to bedside: lessons from drug therapies
}

Thekkeparambil Chandrabose Srijaya', Thamil Selvee Ramasamy ${ }^{2}$ and Noor Hayaty Abu Kasim ${ }^{*}$

\begin{abstract}
The inadequacy of existing therapeutic tools together with the paucity of organ donors have always led medical researchers to innovate the current treatment methods or to discover new ways to cure disease. Emergence of cell-based therapies has provided a new framework through which it has given the human world a new hope. Though relatively a new concept, the pace of advancement clearly reveals the significant role that stem cells will ultimately play in the near future. However, there are numerous uncertainties that are prevailing against the present setting of clinical trials related to stem cells: like the best route of cell administration, appropriate dosage, duration and several other applications. A better knowledge of these factors can substantially improve the effectiveness of disease cure or organ repair using this latest therapeutic tool. From a certain perspective, it could be argued that by considering certain proven clinical concepts and experience from synthetic drug system, we could improve the overall efficacy of cell-based therapies. In the past, studies on synthetic drug therapies and their clinical trials have shown that all the aforementioned factors have critical ascendancy over its therapeutic outcomes. Therefore, based on the knowledge gained from synthetic drug delivery systems, we hypothesize that by employing many of the clinical approaches from synthetic drug therapies to this new regenerative therapeutic tool, the efficacy of stem cell-based therapies can also be improved.
\end{abstract}

Keywords: Cell therapy, Drug therapy, Induced pluripotent stem cells, Mesenchymal stem cells, "Off-the-shelf" stem cell product, Stem cell homing, Stem cell migration

\section{Introduction}

Stem cell technology has generated a great deal of interest in this new era of medical research due to its potential application in regenerative medicine. The two main types of stem cells basically categorized are, embryonic and non-embryonic cells. Embryonic stem cells (ESCs) are derived from the inner cell mass of the blastocyst whereas, non-embryonic stem cells, mostly adult stem cells (mesenchymal stem cells (MSCs); multipotent stem cells (MPCs); progenitor cells (PC) and somatic stem cells (SSC) are specialized cells types found in various tissues within the body [1]. Recently, another type of non-embryonic stem cells, known as induced pluripotent stem cell (iPSCs) was generated through enforced expression of defined transcription factors, which reset the fate of somatic cells to an embryonic stem-cell-like state [1].

\footnotetext{
*Correspondence: nhayaty@um.edu.my

'Department of Restorative Dentistry, Faculty of Dentistry, University of

Malaya, Kuala Lumpur, Malaysia

Full list of author information is available at the end of the article
}

However, ethical controversy and teratoma formation of ESCs and iPSCs hamper their clinical application.

It is generally hypothesized that cell therapy using adult stem cells hold greatest prospect of changing the face of human diseases and alleviating suffering in the near future. Consequently, the therapeutic potential of adult stem cells is the main focus of scientific research; however, in parallel, the ESCs and iPSCs have also been proposed as promising candidates for future therapies due to their pluripotency and personalized therapeutic possibilities [2]. In fact, a number of useful lessons could be learned from these two parallel cell therapy paths to visualize the hurdles to overcome as we move forward these therapies.

The use of stem cell therapy for many human clinical trials is a relatively new concept in the biomedical field [2]. Since the first successful attempts on bone marrow transplant for treating leukemia [3], a number of similar trials were initiated for treating several other diseases [4-8]. After a few decades from its first demonstration of 
successful clinical trials, stem cells treatments now hold a promising impact to treat various degenerative and genetic diseases including certain type of cancers $[9,10]$, neurological diseases [11], autoimmune diseases [12] restoration of sight [13], wound healing [14], cardiac diseases [15], liver diseases [16], metabolic disorders [17], spinal cord injury [18] and bone disorders $[19,20]$. Thus, stem cell therapy has received stunning applause from the majority of the world population, in a hope that is expected to cater the need for diseases treatment and personalized medicine.

In the near future, it is anticipated that stem cell therapy would surpass the conventional synthetic drug therapy, which is the only treatment modality currently available for many illness. A question still remains however: can stem cells themselves can be considered as a biological drug? If we consider them as a drug, in fact, both synthetic drugs and stem cells have similar purpose in their role to cure diseases. Indeed, both therapies aim to achieve the same goal, but they are unparallel in their administration and clinical handlings due to their biochemical properties and mechanism of action in delivering their curative effects. However, it provides better opportunities to yield a more fruitful outcome if certain translational clinical concepts are merged from both therapies to formulate effective treatment strategies. Thereby, we hypothesize that the approach in curing disease through biological means can be more beneficial if we could adopt certain concepts of synthetic drug therapies, which in turn would become decisive factors. In fact, the current stem cell-based therapy in clinical trials has not yet attempted many of the concepts practiced in synthetic drug delivering systems. Nonetheless, it is anticipated that by adopting some effective strategies or procedures from synthetic drug therapy into stem cellbased therapies, an increased efficacy of the treatment could be expected.

\section{Current challenges in developing effective stem cell therapy} At present, the therapeutic use of stem cells poses some challenges because the underlying mechanism of action of the transplanted cells are largely unknown. Indeed, a better understanding of the properties and behaviour of these stem cells and their mechanism of action may open up an avenue for development of targeted therapies for various diseases. In fact, some critical factors have to be thoroughly considered before aligning and integrating the stem cells with the host tissues for long term beneficial outcomes.

\section{Heterogeneity and inherent differential potency of stem cells}

Stem cells for therapeutic applications can be of autologous or allogeneic sources. Within our bodies they normally reside in complex environments and constitute heterogeneous populations [21]. Neglecting cell heterogeneity is one of the major causes of error in cell therapy. Naturally, stem cells are programmed to divide continuously and remain undifferentiated if the environment permits. Thus, the cells require proper signals or cues from neighbouring cells and the microenvironment in which the cells reside. Variations in cell to cell or cellenvironmental signalling responses can alter the functional pathways of these residing cells [22]. Understanding of heterogeneity and cell potency, therefore, will aid in strategic clinical trials [23]. Hence, to interpret the inherent propensity of stem cells is a prerequisite to choose the right cell for the right application and therapy.

\section{Heterogeneity of disease progression}

Another critical area that requires intense attention and is essential to the ultimate success of cell therapies is to explore the disease progression rate for developing tailormade therapy with long-lasting results. This requires detailed information about the disease especially degenerative disorders to offer more personalized treatment [24]. With the advent of breakthrough in regenerative medicine such as induced pluripotent stem cells (iPSCs), there is an immense opportunity to revolutionize the way human diseases are studied, especially the genetic disorders. Creating iPSCs from patients with rare and common diseases is very useful for disease modelling in providing a platform to study the disease progression and drug development to correct the disorder [24]. This approach could be very advantageous in demonstrating the underlying molecular mechanisms, as most illness are no longer considered as single disease entities but subdivided into many factors or subtypes [25]. Given the heterogeneity and complexity of the disease, the initial implication of stem cell treatment could be tailored to an illness and later to an individual context [25]. This could move therapeutic and treatment decisions in a more systematic and target oriented approach. Such attempts can be more or less, a trial-and-error process at the beginning of the treatment but could spike the clinical efficacy of this modality.

\section{Homing and targeted stem cell delivery}

Stem cells offer exquisite cell therapy due to their environment sensing cytokine receptors enabling these cells to migrate towards gradients of chemokine secreted by damaged tissues or tumors [26-28]. The ability of stem cells to either passively home into tissue organs or actively home into diseased sites supports the rationale for the targeted delivery [26]. Along with the native stem cell homing properties, induced-homing has been exploited for more targeted therapeutic vehicle. Much of such targeting translation have been approached by altering the cells in various ways; like substituting cell 
membranes with appropriate receptors [26,28], exercise lipid based particles for delivering genetically modified cells $[27,29,30]$, use of viral vectors for gene delivery [31-33] and use of antibody or peptide conjugated particles $[27,34]$ based on therapeutic requirement to deliver the cells of interest to the target sites. Despite the various homing mechanisms, only a very small fraction of the implanted cells migrate to desired sites, with rates of engraftment depending on method of administration. Accordingly, cell targeting efforts can be enhanced by ideal physical route, utilization of physiological forces for improving cell concentration, preconditioning of cells and introduction of transgenes which can effectively activate the cell homing process [27,32,35-37]. However, additional efforts are still needed for better indication of the stem cell behaviour and the target tissue microenvironments for using such strategies singly or in combinations to deliver the best possible therapeutics in clinical practice.

\section{Complexity of mechanism of action of cell therapy}

The key challenge in considering novel therapies is to analyze the complex biochemical and physiological events that occur during therapeutic implications, by using animal models before translating such therapies to humans [33]. Cell therapies have often been adopted into clinical practice based on their safe and reproducible beneficial outcomes [33]. In terms of clinical practice, the basic therapeutic window is the prevention or reversal of a disease progression. In cell-based therapy both this approaches involves overlapping and differing mechanisms, which should be considered for tailor-made therapy, for disease specific clinical needs [38]. Figuring out the various possible bio-therapeutics such as antiapoptotic, immunomodulation, anti-scarring, angiogenesis, paracrine signalling, chemo attractions and release of supporting growth and differentiation factors for local stem and progenitor cells is a daunting task to define the biochemical pathways and complex inter-molecular machinery involved in cell therapy [39,40]. Embracing the complexity of the cell, requires further research focused on the underlying behaviour and functions as one of the compelling requirements of cell therapy platform to improve the predictive power of stem cells $[40,41]$.

\section{Hypothesis}

Despite the success of several clinical trials using stem cellbased therapy, there are findings reporting the failure in treating diseases [41-45]. Infact, many questions about this technology associated with the best cell type, suitability of homogeneous or heterogeneous cell mixture, delivery method, or route of administration still remains unclear or are under intense investigations. A detail that is often overlooked in the process of stem cell-based therapy is the discrepancy and inadequate cell articulation in treating many of the ailments [46]. Perhaps, this inconsistency might be due to the inappropriate functionalized strategies deployed for therapeutic effects. This severely compromises the potency of the transplanted cells, thereby, limiting their beneficial effect. Hence, to overcome this constraint, we propose that the efficacy of stem cell-based therapy could be enhanced to the highest level by following some of the basic approaches followed in synthetic drug usage. Thus, we hypothesize that the development of strategies from drug therapies pertaining to co-administration, mode/route, site, doses, duration and also the preconditioning of stem cells will allow the restoration of the functionality in injured or diseased organ/tissue and also to decrease unanticipated clinical effects (Figure 1). This approach could be helpful for fulfilling the potential promise of this most exciting power of body's own repair kit to cure diseases.

\section{Strategies to increase the efficacy of stem cell therapy from drug therapies}

Considering the most pressing cell therapy challenges, development of innovative pathways is highly recommended because conventional approaches have some limitations as far as efficacy is concerned. To address these challenges, concepts from pharmaceutical drug research is highly recommended to harness the power of stem cells for improved, long-lasting outcomes. The success in pharmaceutical research is highly dependent on the evaluation of the drug-disease relationship. The process of following such relationship is attained by a series of therapeutic interventions, which requires the identification of a broad range of biomedical data sources. Such accumulating evidence has led to the adoption of certain key approaches in cell therapies from lessons learned in pharmaceutical drug setting.

\section{Co-administration}

In clinical practices, doses or levels of therapy need to be tuned based on the severity of the illness or other metabolic characteristics of the patient's underlying condition. Employing a range of therapies could provide physicians with the flexibility to formulate an effective therapy which is tailor-made for the patient because it takes into consideration the nature and stage of the disease progression. In this regard, there is now an increasing interest in the co-administration of drugs or biomolecules which are often reformulated into fixeddose combinations [47]. The benefits are numerous; for example, drugs can be used in lower concentration which may diminish both the side effects and the treatment costs. Additionally, treatments can be personalized to individual needs [48]. Ye et al. [49] and Rosanio et al. [50] have previously drawn attention to the benefits yielded from the co-administration of low-dose atorvastatin drug when combined with other agents that targeted the 


\section{Cell therapy approaches : Lessons from drug therapies}

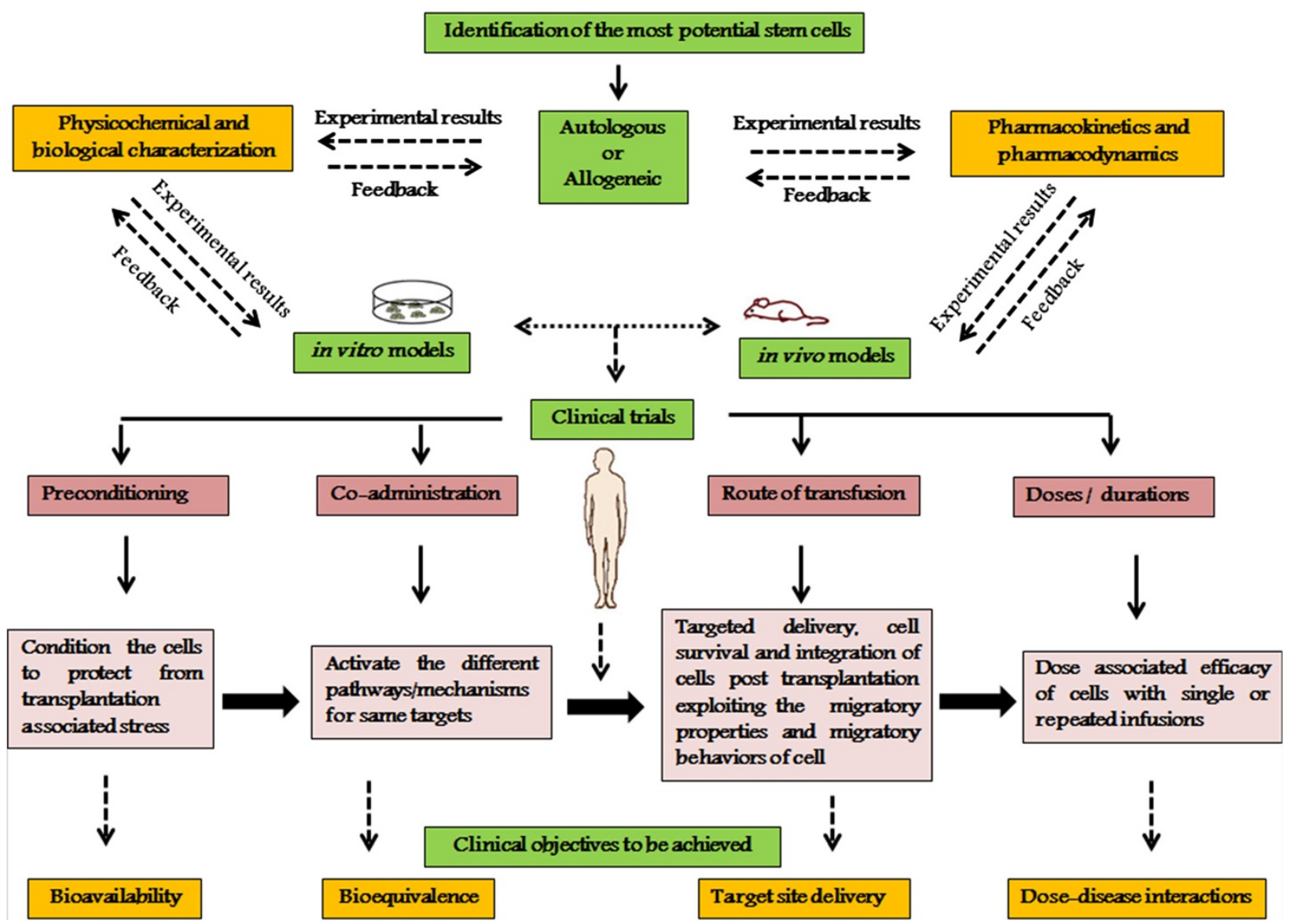

Figure 1 Schematic outline of functional therapeutic approaches for stem cell based-therapy. Development of therapeutic approaches for stem cell-based therapy in consideration of the parameters to be optimized and validated for beneficial clinical outcome. The preliminary approach of the selection of most potential stem cell source (autologous or allogeneic) is followed by characterization for the physicochemical, biological, pharmacokinetics and pharmacodynamics properties of these cells at in vivo and in vitro levels before clinical trials. To further enhance the therapeutic potential of these cells at clinical trial stage, certain concepts from pharmaceutical drug therapies like preconditioning, co-administration, route of delivery, dose and duration of treatment is to be optimized and validated for more effective outcomes. Therapeutic benefits like bioavailability, bioequivalance, targeted delivery and dose associated disease response are to be anticipated by such clinical approaches to enhance the efficacy of the treatment.

specific pathological conditions associated with cardiovascular disease. These researchers demonstrated that co-administration of low dose atorvastatin with either pioglitazone or sildenafil have significantly reduced the infarct size in an animal model with myocardial ischemiareperfusion injury. These results demonstrated how two different agents may act synergistically, via different pathways to activate the same pro-survival targets.

Similarly, we are theorizing here that by co-administrating with different types of stem cells either concurrently or in the course of events can greatly augment the efficacy of stem cell treatment. Our notion is supported by a previous study where co-administration of endothelial and smooth muscle progenitor cells of umbilical cord blood has boosted the efficiency of vessel development in a nude mouse model of critical hind limb ischemia [51]. Additional research also suggested that the combined transplantation of human endothelial cells and mural cells have synergistically improved the blood flow of nude mice of ischemic hind limbs, remarkably, compared to the single cell type transplantations [52]. Several other studies showed the increasing use of hematopoietic stem cell transplantation with umbilical cord blood to treat malignant and non-malignant hematologic diseases [53-57].

In light of these findings, the use of multiple cell types, or genetically engineered cells, or combinations of progenitor cells with cytokines, growth factors, or even clinically proven drugs can greatly increase the therapeutic potential. Further studies to interrogate the molecular mechanism of these approaches would, therefore, give better insight for the formulation of effective treatment. 


\section{Pre-conditioning}

Pharmacological preconditioning is potentially a strong therapeutic tool. Preconditioning has shown to be involved in the protective effect from some membranotropic drugs on activation of metabolic processes, thereby improving the resistance of cell structures to various stress factors, in particular ischemia (glycolysis, protein synthesis and phosphorylation of membrane proteins etc.) and hypoxia [58-62]. Therefore, pharmacologic preconditioning by various types of drugs, culture conditions and physical stimulus has opened up a new perspective to protect organs or tissues from transplantation-associated injury, thereby enhancing the success of transplantation therapy [63]. Likewise, stem cell preconditioning and programming by physical, chemical, genetic, biomolecules and pharmacological manipulation of the cells has shown promise and "prime" the cells to the "state of readiness" to withstand the rigors of lethal ischemia in vitro as well as post-transplantation $[64,65]$. Genetic programming, however, is considered to be unsafe due to the introduction of foreign genetic material into cells which could lead to tumor formation. Therefore safer reprogramming and programming methods such as recombinant protein-based or histone modification-based reprogramming, which provide alternative safer methods for pre-conditioning stem cells could be an alternative. For instance, the generation of induced pluripotent stem cells using recombinant proteins [66] and use of valproic acid to induce pluripotency to amniotic fluid stem cells is a transgene free approach [67].

One of the major challenges of stem cell transplantation from bench to bedside is to maintain the cell survival hindering the manipulation of stem cells before transplantation. This is due to the pro-apototic signals presence in the culture environment, which acts on the cells upon their dissociation. Preconditioned stem cells and progenitors generally showed improved characteristics such as better cell survival, increased differentiation potential, enhanced paracrine effect, efficient homing and integration at site of injury or diseased tissue/organ upon transplantation [68]. Continuous effort in understanding the biological behaviour during manipulation and bioprocessing of stem cells for transplantation have led to the identification of few small molecules which could mask the cells from apoptotic signals while harvesting them from monolayer. One such molecule is ROCK inhibitor, which has been proven to enhance the survival of the stem cells that undergo long bioprocessing and transplantation procedures $[69,70]$.

Recent studies on cardiovascular diseases have also shown that preconditioning of stem cells (bone marrowderived MSCs, adipose-derived stroma cells) could play a vital role in cardio-protection and it has also enhanced the therapeutic efficacy invariably. These studies have successfully used a variety of pre-conditioners including: transforming growth factor-alpha [71]; hypoxic condition [72]; stromal-derived factor 1-alpha [73]; mitochondrial reactive oxygen species [74]; trimetazidine (1-[2,3,4trimethoxybenzyl] piperazine [75]. Hence, preconditioning could be suggested as a viable option for overcoming one of the critical barriers of stem cell therapy such as the rapid decline in viability and function of the transplanted cells, which otherwise greatly compromise the potency of those transplanted cells [76,77]. Nevertheless, cellular preconditioning could enhance all the trophic mechanisms (intracrine, autocrine, and paracrine signals), the expression of survival signalling molecules, and microRNAs, which could confer the cytoprotective effect [77]. Selective upregulation of survival and protective molecules like hypoxia-inducible factor-1 (HIF-1), trophic/ growth factor, Protein Kinase B (PKB/AKT), focal adhesion kinase (FAK), extracellular signal-regulated kinase (ERK), glycogen synthase kinase-3ß (GSK-3ß), matrix metalloproteinase-2 (MMP-2), survivin and Bcl-2 are responsible for protective signalling in response to preconditioning stimuli [78,79]. One of the documented mechanisms of pharmacological preconditioning explains the significant role of mitochondria in cytoprotection by preventing mitochondrial permeability transition pore induction [78]. This is achieved by activating mitochondrial ATP-sensitive potassium (mitoK $\mathrm{ATP}_{\text {) }}$ channels by preconditioning agents, which attenuates the mitochondrial $\mathrm{Ca}^{2+}$ overload thus preventing mitochondrial permeability transition pore induction. Additionally, preconditioning can induce the upregulation of heat shock proteins, which facilitates translocation of gap junction proteins like connexins $\mathrm{Cx} 43$, an important mediator between adjacent cells in the form of hemichannels. Opening of $\mathrm{Cx} 43$ hemichannels helps in early communication between the transplanted and host cells $[78,80]$. This will be of great significant factors to achieve a better communication between cells which will subsequently ease the engraftment and functionality of the transplanted cells at target site.

Another significant element of endogenous preconditioning mechanisms involves the up-regulation of stromalderived factor -1 (SDF-1) and CXCR4 factors which play critical roles in mobilization, homing and engraftment of stem cells $[78,81,82]$. The migration and homing efficacy by SDF-1-CXCR4 chemotaxis is activated mainly by focal adhesion kinase (FAK) through JAK2/STAT3 signalling [78]. Alternatively, P13K/Akt/eNOS signalling also have been reported to trigger the SDF-1 mediated migration of stem cells [78], in which these signalling pathways also play a major role in proliferation and survival of cells. Though found effective, still many of the tissue engineering studies haven't explored the potentiality of pre-conditioning. Therefore, we emphasise that treating the cells with exogenous agents such as conventional 
drugs, bioactive molecules, specific growth factor and signalling molecules during ex vivo expansion before transplantation could greatly increase the efficacy of stem cell therapy.

\section{Route of transfusion}

Whenever new methods or routes are introduced for synthetic drug administration, it becomes vitally important to gain better insight into their pharmacokinetics and pharmacodynamic implications [83]. For any drug to exert its pharmacological effect, it must first gain its entry into the body, followed by absorption into the blood stream, which finally transports or distributes them to its target of action. However, certain factors are found to influence the process of drug absorption and restrict the efficacy of treatment. These include the physicochemical properties of the drug which determine transfer across cell membranes, formulation or physical state of the drug, site of absorption, circulation at absorption site and area of absorbing surface [83]. Absorption site or the port of entry, the speed, ease, and degree of absorption are determined by the route of drug administration [83].

Similarly, a better understanding on the route of administration for efficient viable cell delivery becomes a necessity for stem cell therapies $[84,85]$. However, little is known regarding the optimal delivery strategy for stem cells due to the inadequacy of the tools to label and track those transplanted cells. To date, depending on the patient condition, a variety of stem cell delivery options have been adopted based on preclinical and clinical studies for repairing different tissues like cardiac tissue (intracoronarily, intramyocardial, catheter-based injections) [86-90]; brain (intracranial, intravenous, intranasal, circulatory systems) [91-93] and spinal cord (intra-arterial, intravenous; cerebrospinal fluid by lumbar puncture) $[94,95]$. However, several studies have revealed that route of stem cell (MSCs) administration near to the target site have shown more potential than the other routes of administration [96-99]. In some other studies multiple route delivery technique has shown substantial advantage over the single route administrating techniques, to ensure the cell homing to the target area to promote tissue repair [100]. Although, the complexity of multiple route delivery limits the mechanistic understanding of cell- based applications, the feasibility of safe and assured delivery to the target niche ensures the endogenous repair which is greatly demanding criterion, due to heterogeneity of human injuries. Hence, for the success of any stem cell therapy, we suggest that finding the right route for cell administration is of prime importance. This is only achievable by understanding the migratory property of these cells and the cell behaviour along the migratory route. Moreover, it has to be made sure that the transplanted cells are not homing, other than the area of interest of organ repair, otherwise it could lead to disturbance of normal homeostasis in the function and regulation of other organs [57]. Therefore, we propose that the approach of stem cell therapy should be basically target specific and the cell administration to achieve this target specificity [101]. Thus, developing tools to label and track those transplanted cells, prime the cells to adopt the migration potential and co-administrate factors to effectively induce the repopulation of integrated stem cells would be of great benefit to make cell therapy a success.

\section{Treatment modalities: doses and duration}

Every patient has a unique therapeutic threshold for each prescribed drug due to individual drug sensitivities $[102,103]$. Age and gender, are two other significant factors which influence the pharmacokinetics and pharmacodynamics of a drug [104,105]. Hughes and Aronson [106] defined that duration of action of a drug is directly proportional to the logarithm of dose for a wide range of different drugs, revealing the significant role played by both these variables on the treatment outcomes. Therefore, when drugs are administrated, a meticulous understanding of the dose-response relationship is of great significance for achieving the specific therapeutic effect while minimizing their side-effects $[107,108]$. Generally for stem cell based treatment, a $70 \mathrm{~kg}$-patient needs approximately $2 \times 10^{6}$ MSCs per kilogram body weight for transplantation [109]. However, reports suggest that there are variations in optimal or effective doses required for various diseases, albeit the source of the stem cells is the same. For examples, $3-5 \times 10^{7}$ cell $/ \mathrm{kg}$ exvivo expanded autologous bone marrow derived mesenchymal stem cells (BM-MSCs) were administrated into each patient with multiple sclerosis [110] whereas in spinal cord injury, 5-6 $\times 10^{6}$ cells $/ \mathrm{kg}$ were transplanted [111]. Liang et al. [112] reported that a dose of $1 \times 10^{6}$ cells $/ \mathrm{kg}$ allogeneic bone marrow MSCs were transplanted via intravenous infusion through a single administration for treating refractory systemic lupus erythematosus. Clinical trials for graft-versus-host disease (GVHD) using allogeneic MSCs (adipose derived stem cells, bone-marrow derived MSCs, hematopoietic stem cell, peripheral blood stem cell, Prochymal) demonstrated beneficial responses in both pediatric and adult patients when infused (single to multiple times) with different doses based on severity of the disease [1]. Similar studies of dose escalation phase I clinical trial using different doses of allogeneic MSCs (Prochymal) ranging from $0.5,1.6$, and 5 million cells $/ \mathrm{kg}$ in patients with myocardial infarction showed safety efficacy data [113]. An overall assessment of the patient health was evaluated during the course of trial for signs of improvement or deterioration. Significantly, when analyzed for dose-dependent effects, patients exhibited dose responsiveness in terms of 
premature ventricular contraction (PVC). The PVC count did not differ in the control and low dose treatment groups, but variation was evident in the mid and high dose treatment groups. In yet another pilot study, phase I/II clinical trials was conducted for demonstrating the efficacy of allogeneic bone marrow derived MSCs in patients with chronic ishemic cardiomyopathy (ICM) [114]. Currently, phase I clinical trial is being conducted on dose escalation study of autologous MSCs in patients with Amyotrophic Lateral Sclerosis for determining the dose limiting toxicities [115,116]. In another study, dose escalation Phase 2 clinical trial of MultiStem (allogenic cell therapy treatment comprising of multipotent adherent bone marrow cells) in patients with ischemic stroke was measured with two dose tiers of 400 million and 1200 million cells per patient to determine the highest well-tolerated and safe single dose of multistem [117]. Further clinical trials are being conducted for dose-escalating therapeutic study of allogeneic bone marrow derived mesenchymal stem cells for the treatment of fistulas in patients with refractory perianal crohn's disease [118].

While study results provide assurance for the safety of allogeneic human mesenchymal stem cells (hMSCs), further work is in demand to delineate the mechanism of action of this MSC therapy in dose responsiveness manner. In addition, other factors such as source of stem cells, their functionality level, disease stage and route of administration, niche microenvironment can also influence the dosage and duration of stem cell therapy for a particular disease. For example, studies have reported poor engraftment of transplanted stem cells which could be due to impaired target niche microenvironment after intensive chemoradiotherapy or lower doses of cell infusion [57]. Hence, development of dose-intensive delivery programs can possibly improve the response rates and outcome of treatment. Further evaluation of the efficacy in terms of safety and functional outcome of repeated dose/duration period can result in major advance in stem cell treatment strategies when compared to conventional therapy.

Although, promising results have been highlighted using MSCs in clinical trials, the underlying dose and follow up dose associated mechanisms still remains unclear. Nevertheless, studies involving MSC therapy demonstrates a clear involvement of intricate mechanism of migration, homing efficiency, immunological properties, differentiation and secretions of bioactive molecules in an integrative manner. Taking all these notes together, it is possible that dose associated potential efficacy of allogeneic/autologous stem cells with single or repeated infusions can translate significant changes in clinical aspects. Further, it is plausible to propose that treating a disease with terminally differentiated cells would require higher cell number than by progenitors because the latter option provides the opportunity for this cell to proliferate and produce a larger mass and may differ in its secretions of bioactive molecules to substitute or repair the lost functional tissue. However, the unique tropism of cell therapy has to be taken into account for the optimization of cell infusion doses and duration to prevent cell losses for an effective transplantation setting. Taking all these issues together, stem cell therapy has a great potential to evolve further answers to the challenges associated with cell therapy transplantations as to ensure reproducible personalized therapy (Figure 2).

\section{Therapeutic road map differ between autologous or allogeneic (off the shelf) cell products}

Globally there are between 300 to 700 companies, ranging from small university spinouts to multinational corporations involved in developing cell-based therapy such as GlaxoSmithKline, Johnson \& Johnson, Pfizer, and Sanofi (Genzyme) [119]. Persistent development of cell-based therapy research and development (R\&D) industrial players in stock market index suggests the demand and potential of this industry as a distinct healthcare sector (119) Table 1. Clinical transplantation mostly set to utilize allogeneic or syngeneic (genetically similar) donor cells due to the complications/difficulties in extracting or obtaining ample patient-derived cells. One main reason for this phenomenon is that aging and disease pathophysiology affect the number and functional properties of stem cells in patients $[3,120]$. Besides, allogeneic cells can be readily isolated from healthy donors and thus can be used as an "off-the-shelf" biological reagent. Furthermore, precultured human stem cells offer an improved practicality in consideration for cell therapy than compared with on-site isolated autologous cells. Firstly, the homing ability of allogeneic MSCs to injured site or tissue could be well stimulated during culture by manipulating the expression of SDF-1/CXCL12 axis, which in turn induces the migratory ability [113]. Second, the lack of various major histocompatibility complexes (MHC) and co-stimulatory cell-surface antigens makes them a perfect allogeneic graft, additionally having the conferred anti-inflammatory properties [113]. For instance, the host immune system cannot detect the donor MSCs (allogenic graft) on account of low levels of human leukocyte antigens (HLA) present on surface of these cells [1]. Third, it offers an enriched population of therapeutically relevant cells, as demonstrated in various pre-clinical studies [113]. Finally, the differentiation potential of stem cells into tissue specific cells of different lineages is advantageous [1].

Although the differentiation potential of embryonic stem (ES) cells is greater than of somatic stem cells, studies have proven that MSCs can be conferred into more pluripotent state by epigenetic modification which facilitates an efficient differentiation into cells of different lineages [1]. Hence, this approach makes MSCs suitable for the treatment of various disease pathologies and injuries. 




In some instances, there are studies addressing the safety concerns associated with the preparation of allogeneic cells, which showed a detectable level of HLA once they are integrated and differentiated in the host. This leads to the graft rejection and chronic immune responses [141]. Therefore, issue over such graft rejection even when the cells expresses HLA at low level, in turn makes the autologous and minimally in vitro manipulated cells as an attractive and promising curative bio-reagents for many regenerative, antiinflammatory and autoimmune related diseases. Indeed, studies have revealed the suitability of both autologous and allogeneic culture-expanded MSCs in cardiovascular studies [114], in which direct myocardial injection of autologous expanded BM-MSCs was found to show significant effect in structural and functional measures for ischemic Left Ventricular dysfunction [142]. While the attempt to utilize the autologous MSC to achieve individual treatment has been the focus for the past few decades, application of these cells through fibrin spray or in the form of conditioned media (culture media of MSCs consisting of cell secretions) are also under investigation for treatments like wound repair, burns and other soft and connective tissue repair [143-145]. Having said this, factors such as nature of the disease, type of stem cells and patient condition need to be taken into consideration before formulating an effective procedures and approach to utilise autologous and allogeneic cell-based therapy (Figure 3).

A great new venture in which the cell therapy based industry moving towards is the generation of patient specific induced-pluripotent stem cells (iPSCs), bringing a whole new dimension in developing cell based therapy to the next level moving this endeavour from bench to bedside application. Various aspect of biological properties and therapeutic models are under investigation in order to develop such patient specific stem cells. Although, a recent study has reported limited immunogenicity of transplanted cells differentiated from iPSCs and embryonic stem cells [146], the immunological barriers of patient specific- cell transplantation are the same as those encountered and continue to confound for allogeneic cells. Indeed, long 
Table 1 Stem cell therapy companies and their cell products in development

\begin{tabular}{|c|c|c|c|c|}
\hline Company name & Cell types & Therapeutic programs/product name & Clinical area & Reference \\
\hline \multirow[t]{2}{*}{ Aastrom Bioscience } & \multirow[t]{2}{*}{ Autologous } & \multirow{2}{*}{$\begin{array}{l}\text { Multicellular therapy } \\
\text { (Ixmyelocel-T) }\end{array}$} & Cardiovascular disease & \multirow[t]{2}{*}{ [121] } \\
\hline & & & Peripheral artery Diseases (PAD) & \\
\hline \multirow[t]{4}{*}{ Cytomedix } & \multirow[t]{4}{*}{ Autologous adult stem cells } & \multirow{4}{*}{$\begin{array}{l}\text { ALDHbr (autologous regenerative cell therapy utilizing } \\
\text { proprietary ALDH Bright Cell technology to isolate } \\
\text { biologically active pluri-potent stem cells for therapeutic use) }\end{array}$} & Ischemic heart failure & \multirow[t]{4}{*}{ [122] } \\
\hline & & & Ischemic Stroke & \\
\hline & & & Critical limb ischemia & \\
\hline & & & Peripheral artery Diseases (PAD) & \\
\hline \multirow[t]{7}{*}{ Cytori Therapeutics } & \multirow{3}{*}{$\begin{array}{l}\text { Autologous adult adipose derived } \\
\text { stem cells }\end{array}$} & \multirow{7}{*}{$\begin{array}{l}\text { Celution } \mathbf{8 0 0 / C R S ~ s y s t e m ~ ( T h e ~ s y s t e m ~ a u t o m a t e s ~ a n d ~} \\
\text { standardizes the extraction and concentration of patients } \\
\text { own Adipose Derived Regenerative Cells (ADRCs) in a clinical } \\
\text { setting, enabling real-time access to autologous medical } \\
\text { grade cells ADRCs }\end{array}$} & Acute Ml & \multirow[t]{7}{*}{ [123] } \\
\hline & & & Cardiac failure & \\
\hline & & & Burn care & \\
\hline & \multirow{4}{*}{$\begin{array}{l}\text { Regenerative cells produced utilizing } \\
\text { proprietary }\end{array}$} & & Soft tissue injury & \\
\hline & & & Orthopedics & \\
\hline & & & Breast reconstruction & \\
\hline & & & Sports medicine & \\
\hline Dendreon & Autologous cellular immunotherapy & $\begin{array}{l}\text { Provenge (sipuleucel-T) Body's own immune cells are } \\
\text { isolated and reprogrammed to attack advanced prostate cancer. }\end{array}$ & $\begin{array}{l}\text { Prostate cancer (asymptomatic/ } \\
\text { minimally symptomatic } \\
\text { metastatic castrate) }\end{array}$ & [124] \\
\hline \multirow[t]{2}{*}{ Fibrocell Science } & \multirow[t]{2}{*}{ Autologous Fibroblasts } & Azficel-T s BLA Program & Skin & \multirow[t]{2}{*}[125]{} \\
\hline & & $\begin{array}{l}\text { Intrexon Synthetic Biology Rare Disease Program } \\
\text { (Autologous cellular product treat rare and serious skin } \\
\text { and connective tissue diseases and conditions) }\end{array}$ & Connective tissue diseases & \\
\hline \multirow{4}{*}{$\begin{array}{l}\text { Immuno cellular } \\
\text { therapeutics }\end{array}$} & \multirow[t]{4}{*}{ Autologous dendritic cell } & ICT- 107 (newly diagnosed Glioblastoma) & Glioblastoma multiforme & \multirow[t]{4}{*}[126]{} \\
\hline & & ICT- 121 (Recurrent Glioblastoma) & Ovarian cancer & \\
\hline & & ICT- 140 (Ovarian cancer) & Cancer stem cells & \\
\hline & & Autologous dendritic cell based vaccines & & \\
\hline \multirow{3}{*}{$\begin{array}{l}\text { Japan Tissue Engineering } \\
\text { Company (J-TEC) }\end{array}$} & \multirow[t]{3}{*}{ Autologous cell } & Autologous cultured epidermis & Burns & \multirow[t]{3}{*}{ [127] } \\
\hline & & Autologous cultured Cartilage & Cartilage defects & \\
\hline & & $\begin{array}{l}\text { Autologous cultured Corneal Epithelium } \\
\text { (Tissue engineering using autologous cells) }\end{array}$ & Corneal damage & \\
\hline \multirow[t]{2}{*}{$\begin{array}{l}\text { Northwest } \\
\text { Biotherapeutics }\end{array}$} & \multirow[t]{2}{*}{ Autologous dendritic cells } & \multirow[t]{2}{*}{ DCVax technology (Autologous dendritic cell-based therapy) } & $\begin{array}{l}\text { Glioblastoma multiforme } \\
\text { (brain tumor) }\end{array}$ & \multirow[t]{2}{*}{ [128] } \\
\hline & & & Prostate cancer & \\
\hline Pharmicell & Autologous bone marrow derived MSCS & Hearticellgram (Autologous bone marrow derived MSCs) & Acute Myocardial Infarction & {$[129]$} \\
\hline
\end{tabular}

Provenge (sipuleucel-T) Body's own immune cells are

\section{Azficel-T s BLA Program}

ICT- 107 (newly diagnosed Glioblastoma)

Autologous dendritic cell based vaccines

Autologous cultured Corneal Epithelium

(Tissue engineering using autologous cells,

Hearticellgram (Autologous bone marrow derived MSCS) 
Table 1 Stem cell therapy companies and their cell products in development (Continued)

\begin{tabular}{lll}
\hline $\begin{array}{l}\text { Advanced Cell } \\
\text { Technology }\end{array}$ & Allogeneic adult stem cells hESC-derived \\
cells & $\begin{array}{l}\text { Retinal Pigment Epithelial Cell Program for: } \\
\text { Stargardt's macular dystropy (SMD) }\end{array}$ \\
& $\begin{array}{l}\text { Dry Age-Related Macular Degeneration (AMD) } \\
\text { Hemangioblast (HG) Program for: Diseases and disorders } \\
\text { of circulatory and vascular system } \\
\text { Athersys }\end{array}$ & Multistem
\end{tabular}

Retinal Degenerative Conditions

Blood and cardiovascular diseases

\section{Multistem}

Inflammatory \& Immune

Neurological

Cardiovascular disease

Ulcerative colitis

Ischemic stroke

BioTime Clinical-grade human embryonic stem (hES) cell lines

OpRegen (hESC-derived RPE cells for the treatment of macular degeneration)

OPC1 (hESC-derived oligodendrocyte progenitors for spinal cord injury):

VAC1 (a dendritic cell-based vaccine for cancer based on the telomerase antigen)

Cartistem (cartilage defect)

Allogeneic human umbilical cord blood and Umbilical Cord Blood derived Mesenchymal Stem Cells (hUCB-MSCs)

Neurostem (neuro-degenerative disorders)

Pneumostem (pulmonary disorders)

Promostem (early engraftment of donor hematopoietic stem cells (HSCs))

Allogeneic adult derived mesenchymal

Proprietary Mesenchymal stem cells lineage technology precursor cells (MPCs)

Mesenchymal stem cells (MSCs)

Dental pulp stem cells (DPSCs)

Hematopoietic stem cells (HSCs)

Autologous adult stem cells,

Targeted Immuno Therapy Program

Allogeneic T cell Embryonic like stem cells \& Progenitor Cells

\section{CD34 cell program}

T Regulatory Cell Program

VSEL (Very small embryonic like stem cells ) technology

Human hippocampus Neural Stem cells

NSL-189 (a compound developed for oral administration for psychiatric and cognitive disorders)

Spinal cord injury

Neuroscience orthopedics blood and vascular diseases oncology

Cartilage defects

Alzheimer's disease

Amyotrophic Lateral Sclerosis (ALS)

Stroke

Chronic lung disease (premature babies)

Systemic diseases with underlying inflammatory and immunologic etiology

Cardiac and vascular diseases

Orthopedic diseases of spine

Improving outcome of bone marrow transplantation

Cancer treatment

Ischemic repair

Immune modulation

Tissue regeneration

Amyotrophic Lateral Sclerosis (ALS)

Traumatic brain injury

Alzheimer's disease 
Table 1 Stem cell therapy companies and their cell products in development (Continued)

\begin{tabular}{|c|c|c|c|c|}
\hline \multirow[t]{4}{*}{ Osiris Therapeutics } & \multirow{4}{*}{$\begin{array}{l}\text { Autologous and Allogeneic Mesenchymal } \\
\text { stem cells (MSCs) }\end{array}$} & \multirow{3}{*}{$\begin{array}{l}\text { OvationOS (bone matrix designed for the filling of bony voids } \\
\text { and to support bone repair and regeneration) } \\
\text { Grafix (Allogeneic MSCs in extracellular matrix) }\end{array}$} & Bone damage & [137] \\
\hline & & & \multirow{3}{*}{ Soft tissues(cartilage and tendon) wound healing } & \\
\hline & & & & \\
\hline & & $\begin{array}{l}\text { Cartiform (3-dimensional architecture of hyaline cartilage that } \\
\text { contains the necessary cellular and molecular components for } \\
\text { articular cartilage repair, and is primed for mesenchymal stem } \\
\text { cell (MSC) activity) }\end{array}$ & & \\
\hline \multirow[t]{3}{*}{ Pluristem therapeutics } & \multirow[t]{3}{*}{ Allogeneic cells } & \multirow[t]{3}{*}{ PLX (Placental expanded cells) } & Cardiovascular disease & [138] \\
\hline & & & Orthopedic disease & \\
\hline & & & Pulmonary diseases & \\
\hline \multirow[t]{4}{*}{ Stemcells } & \multirow{4}{*}{$\begin{array}{l}\text { Allogeneic tissue derived adult stem cells } \\
\text { and progenitor cells }\end{array}$} & HuCNS-SC (human neural stem cells) & Spinal cord injury & [139] \\
\hline & & \multirow[t]{3}{*}{ hLEC (human liver engrafting cells) } & Peripheral artery Diseases (PAD) & \\
\hline & & & Pelizaeus-Merzbacher Disease (PMD) & \\
\hline & & & Age-related macular degeneration (AMD) & \\
\hline \multirow[t]{3}{*}{ Tigenix } & \multirow{3}{*}{$\begin{array}{l}\text { Autologous and Allogeneic adult stem } \\
\text { cells }\end{array}$} & ChondroCelect (Autologous Chondrocytes) & Cartilage defects & [140] \\
\hline & & \multirow{2}{*}{$\begin{array}{l}\text { eASCs (Allogeneic expanded stem cells extracted from adipose } \\
\text { tissue ) }\end{array}$} & Perianal fistulas & \\
\hline & & & Rheumatois arthritis & \\
\hline
\end{tabular}

ASCs (Allogeneic expanded stem cells extracted from adipose Perianal fistulas

Rheumatois arthritis 




erm culture, genomic instability, interference with matrix structure, genetic manipulation and epigenetic reprogramming can impair immune privilege status of the autologous and allogeneic cells [147]. Accordingly, in such safe personalized regenerative stem cell therapy scenarios, the selection of the least incompatible stem cells, safe generation of stable and clinical grade iPSCs lines in xeno-free and fully defined culture conditions and proper characterization of quality parameters to ensure cell purity and potency along with the host MHC information is to be considered to avoid or attenuate the host immune response to the transplanted stem cells $[147,148]$.

Another approach would be the development of HLAmatched cell banks, which are the focus of stem cell biobank services provided by some of the healthcare industrial players [119]. Considering the surrounding merits of using autologous and allogeneic stem cells, it might be further insightful to gain beneficial information on the immunogenetics by direct comparison between both these cell types and iPSCs and iPSC-derived therapeutically relevant cells to control and ensure successful therapeutic impact upon transplantations. Thus, the use of "off the shelf cell products" is highly attractive in their point-of-care in cell therapeutics. Hence, by ensuring the continued development of the regulatory framework, therapeutics interventions and other supportive technologies by healthcare bodies and industries, it will accelerate this exciting new therapeutic venture and bring impact to the future successes of the cell therapy industry.

Pharmaceutical drug therapeutic lessons translatable and not translatable to stem cell therapies

Both synthetic and natural drugs are generally wellcharacterized of their formulation, biochemical reactions, 
pharmacokinetics, pharmacodynamics and predictable end and by-products. On the other hand, the significant limitations to the development of stem cell therapy for patients includes; a) the lack of knowledge on the active cellular constituent of stem cells that are responsible for the reparative action $b$ ) the possibility that therapeutically active cells may represent only a very small fraction of the total stem cell population and, c) their potential to differentiate into variety of cell lineages govern by the in vivo microenvironment factors. Mostly, pharmaceutical treatments deliver a single agent at a specific dose to either catalyse or inhibit the biochemical reactions. On the other hand, stem cells are site-regulated and they are capable to secrete bioactive factors and give signals at variable concentrations in response to local microenvironmental cues [141]. Thus, while designing cell therapy, the criteria, measurement and outcome one would expect for an optimal combination to specific organs or disease could most likely be variable because of the complexity of the parameters. Hence, understanding the complexity represented by the behaviour and responses of these stem cells requires the development of novel approaches and strategies which are not present in drug therapy and yet to be developed.

Albeit therapies based on drugs and stem cells have to be paved in a different way. Certain critical curative concepts of drugs therapies like the pharmacogenomics will be of high importance in developing cell therapies. In pharmacogenomics, it has been hypothesized that human genetic variations could dictate the efficacy and toxicity of drugs [149]. Thus the genetic information can be utilized to predict the safety, toxicity and/or efficacy of drugs. Accordingly, pharmacogenomics studies are mostly carried out through candidate gene approach and prior knowledge of the drug mechanism. Specific genes that encode for drug metabolizing enzymes, drug transporters and drug related proteins are also considered for screening before treatment. Similarly, cell secretions have a role in an individual's genotype expression [120]. Equivalently, to commensurate the cell therapeutic mechanism for such response reaction could be analysed for the genes of interest and also other relevant genes involved. For instance, those genes involved in the immune response could be used. Thus, the concept of utilizing the role of human genetic variation to such responsive agents (either stem cells or drugs), provide credence to the concept of personalized medicine.

To better understand these factors and to optimize the beneficial effect of these therapies, it is important to monitor the clinical trials and the outcomes. While the best treatment strategy either by employing conventional

Table 2 Strategies to be refined to expand the stem cell therapeutic procedure

\begin{tabular}{|c|c|c|c|}
\hline $\begin{array}{l}\text { Functional therapeutic } \\
\text { approaches }\end{array}$ & Therapeutic strategies & Benefits/outcomes & Problems to be addressed \\
\hline \multirow{6}{*}{ Co-administration } & Multiple cell types & \multirow{3}{*}{$\begin{array}{l}\text { Utilization of cell } \\
\text { heterogeneity }\end{array}$} & \multirow[t]{3}{*}{ Utilization of correct combinations } \\
\hline & Genetically engineered cells & & \\
\hline & Combinations of progenitors & & \\
\hline & Cytokines & \multirow{3}{*}{$\begin{array}{l}\text { Exploiting cell signalling } \\
\text { synergistically }\end{array}$} & \multirow{3}{*}{$\begin{array}{l}\text { Understanding cell signalling for effective cell } \\
\text { formulations }\end{array}$} \\
\hline & Growth factors & & \\
\hline & Transcription factors & & \\
\hline \multirow{5}{*}{ Pre-conditioning } & Chemical (drugs) & Cyto-protection & \multirow{3}{*}{$\begin{array}{l}\text { Developing safer reprogramming \& } \\
\text { programming methods }\end{array}$} \\
\hline & $\begin{array}{l}\text { Physical Stimuli (hypoxia, electrical } \\
\text { stimulation, ultrasound) }\end{array}$ & Better cell survival & \\
\hline & Genetic & $\begin{array}{l}\text { Increased differentiation } \\
\text { potential }\end{array}$ & \\
\hline & Small molecules & Enhanced paracrine effects & \multirow{2}{*}{$\begin{array}{l}\text { Understanding the mechanisms triggering } \\
\text { the cytoprotective and other signalling } \\
\text { pathways in response to preconditioning stimuli }\end{array}$} \\
\hline & Pre-coating & $\begin{array}{l}\text { Efficient homing \& } \\
\text { integration }\end{array}$ & \\
\hline \multirow{3}{*}{$\begin{array}{l}\text { Route of transfusion/ } \\
\text { translation }\end{array}$} & Local or systemic & Targeted delivery & $\begin{array}{l}\text { Developing efficient labelling for cell tracking post } \\
\text { transplantation }\end{array}$ \\
\hline & Intracranial, intranasal, circulatory system & \multirow{2}{*}{$\begin{array}{l}\text { Better cell survival \& } \\
\text { integration post } \\
\text { transplantation }\end{array}$} & Complexity of multiple route delivery mechanisms \\
\hline & $\begin{array}{l}\text { Intra-arterial, intra venous, cerebrospinal } \\
\text { fluid by lumbar puncture }\end{array}$ & & $\begin{array}{l}\text { Understanding the migratory properties \& } \\
\text { migratory behaviour of cells through } \\
\text { different delivery routes }\end{array}$ \\
\hline \multirow{2}{*}{ Doses \& Durations } & Cell dose based on MSCs sources & $\begin{array}{l}\text { Minimize side effects } \\
\text { by fixed dose }\end{array}$ & $\begin{array}{l}\text { Determine the potential cell source for } \\
\text { transplantation }\end{array}$ \\
\hline & Single or multiple infusion & Preventing cell lose & $\begin{array}{l}\text { Determine the dose associated efficacy of } \\
\text { allogeneic/autogenic/cryopreserved MSCs }\end{array}$ \\
\hline
\end{tabular}


drugs or stem cell transplant adds to the socioeconomic considerations, in other situations research investigating the psychosocial experience and quality of life of patients undergoing such treatments should also be considered. Clearly, the beneficial effect of these therapies must be weighed against the risks, but experimental studies must be encouraged to design combinational procedures by exploring newly developed concepts and protocols.

\section{Future perspective of stem cell therapy in regenerative medicine}

Regenerative medicine and cell therapy are poised to have a tremendous impact on the future of medicine by delivering more effective, long-lasting, safe and costeffective therapies for life- threatening and life-altering conditions than are currently available today. The extent to which we are able to achieve effective cell therapies will depend on assimilating a rapidly developing base of scientific knowledge with the practical considerations of design, delivery, and host response. Hence, a continuous effort is required to achieve a refined application of stem cell therapy to expand the role of stem cells for their vanguard uses. Table 2 details the cell therapy strategies, benefits and current challenges to be refined for more effective stem cell therapeutic procedure.

\section{Conclusion}

This hypothesis is aimed to propose the possible mimicking or recapitulation of certain clinical approaches from conventional drug therapy to stem cell-based therapy to improve their efficacy. Adopting such approaches will give immense value in translating stem cell therapy from bench to bedside. In addition to satisfying the scientific basis of stem cell treatments, this approach will bring about viable options to overcome current limitations in stem cell therapy. Implication of this approach in stem cell therapy is expected to not only modulate the outcome of intended therapy, but also will be a feasible option for the cost effectiveness of stem cell-based regenerative therapies in the near future. Therefore we suggest that the stem cells therapy should be also be seen from the point of view drug.

\footnotetext{
Abbreviations

ESCs: Embryonic stem cells; MSCs: Mesenchymal stem cells; MPCs: Multipotent stem cells; PC: Projenitor cells; SSC: Somatic stem cells; HIF-1: Hypoxia-inducible factor -1; Akt: Protein kinase B (PKB); CXCR4: C-X-C chemokine receptor type 4 also known as fusin or CD184; FAK: Focal adhesion kinase; ERK: Extracellular signal-regulated kinase; GSK-3ß: Glycogen synthase kinase-3ß; MMP-2: Matrix

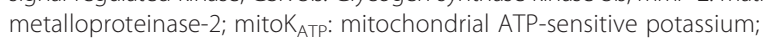
SDF-1: Stromal-derived factor -1; GVHD: Graft-versus-host disease; iPSC: Induced pluripotent stem cells; ICM: Ishemic cardiomyopathy; MHC: Major histocompatibility complexes; HLA: Human leukocyte antigens; SDF-1: Stromal derived factor -1; PAD: Peripheral artery diseases; ADRCs: Adipose derived regenerative cells; ALS: Amyotrophic lateral sclerosis; AMD: Age-related macular degeneration; PMD: Pelizaeus-merzbacher disease; PLX: Placental expanded cells; hLEC: Human liver engrafting cells; HuCNS-SC: human neural stem cells.
}

\section{Competing interests}

The authors declare that they have no competing interests.

\section{Authors' contributions}

TCS wrote the manuscript. All authors reviewed, edited and approved the final manuscript.

\section{Acknowledgements}

The authors gratefully acknowledge vice chancellor of University Malaya through High Impact Research MoE grant (UM.C/HIR/MOHE/DENT/01) from the Ministry of Education Malaysia and University of Malaya Research Grant (UMRG RP 019/13HTM), for providing an opportunity to work on this review article. The authors are also thankful to Dr. Pradeep P.J. and Dr. Anand R for their valuable comments in improving the quality of the review article.

\section{Author details}

${ }^{1}$ Department of Restorative Dentistry, Faculty of Dentistry, University of Malaya, Kuala Lumpur, Malaysia. ${ }^{2}$ Department of Molecular Medicine, Faculty of Medicine, University of Malaya, Kuala Lumpur, Malaysia.

Received: 22 March 2014 Accepted: 26 August 2014

Published online: 04 September 2014

\section{References}

1. Wang S, Qu X, Zhao RC: Clinical applications of mesenchymal stem cells. J Hematol Oncol 2012, 5:19.

2. Picanc, 0 -Castro V, Moreira LF, Kashima S, Covas DT: Can pluripotent stem cells be used in cell-based therapy? Cell Reprogram 2014, 16(2):98-107.

3. Gatti RA, Meuwissen HJ, Allen HD, Hong R, Good RA: Immunological reconstitution of sex-linked lymphopenic immunological deficiency. Lancet 1968, 2:1366-1369.

4. Horwitz EM, Prockop DJ, Fitzpatrick LA, Koo WW, Gordon PL, Neel M, Sussman M, Orchard P, Marx JC, Pyeritz RE, Brenner MK: Transplantability and therapeutic effects of bone marrow-derived mesenchymal cells in children with osteogenesis imperfecta. Nat Med 1999, 5:309-313.

5. Syková E, Homola A, Mazanec R, Lachmann H, Konrádová SL, Kobylka P, Pádr R, Neuwirth J, Komrska V, Vávra V, Stulík J, Bojar M: Autologous bone marrow transplantation in patients with subacute and chronic spinal cord injury. Cell Transplant 2006, 15(Suppl 8-9):675-687.

6. Savitz SI, Misra V, Kasam M, Juneja H, Cox CS Jr, Alderman S, Aisiku I, Kar S, Gee A, Grotta JC: Intravenous autologous bone marrow mononuclear cells for ischemic stroke. Ann Neurol 2011, 70(Suppl 1):59-69.

7. Takami T, Terai S, Sakaida I: Advanced therapies using autologous bone marrow cells for chronic liver disease. Discov Med 2012, 14(Suppl 74):7-12.

8. Trounson A, Thakar RG, Lomax G, Gibbons D: Clinical trials for stem cell therapies. BMC Med 2011, 9:46-52.

9. Sagar J, Chaib B, Sales K, Winslet M, Seifalian A: Role of stem cells in cancer therapy and cancer stem cells: a review. Cancer Cell Int 2007, 7:9.

10. Sales KM, Winslet MC, Seifalian AM: Stem cells and cancer: an overview. Stem Cell Rev 2007, 3:249-255.

11. Hess DC, Borlongan CV: Stem cells and neurological diseases. Cell Prolif 2008, 41:94-114.

12. Van Laar JM, Tyndall A: Adult stem cells in the treatment of autoimmune diseases. Rheumatology (Oxford) 2006, 45:1187-1193.

13. Pellegrini G, De Luca M, Arsenijevic Y: Towards therapeutic application of ocular stem cells. Semin Cell Dev Biol 2007, 18:805-818.

14. Cha J, Falanga V: Stem cells in cutaneous wound healing. Clin Dermatol 2007, 25:73-78.

15. Strauer BE, Brehm M, Schannwell CM: The therapeutic potential of stem cells in heart disease. Cell Prolif 2008, 41:126-145.

16. Wang Z, Lu H, Wang YC, Cong XQ: Human embryonic stem cells and liver diseases: from basic research to future clinical application. J Dig Dis 2008, 9:14-19.

17. Schulze $M$, Fändrich $F$, Ungefroren $H$, Kremer B: Adult stem cells perspectives in treatment of metabolic diseases. Acta Gastroenterol Belg 2005, 68:461-465.

18. Coutts M, Keirstead HS: Stem cells for the treatment of spinal cord injury. Exp Neurol 2008, 209:368-377.

19. Tseng SS, Lee MA, Reddi AH: Nonunions and the potential of stem cells in fracture- healing. J Bone Joint Surg Am 2008, 90:92-98. 
20. Cuomo AV, Virk M, Petrigliano F, Morgan EF, Lieberman JR: Mesenchymal stem cell concentration and bone repair: potential pitfalls from bench to bedside. J Bone Joint Surg Am 2009, 91:1073-1083.

21. Hope K, Bhatia M: Clonal interrogation of stem cells. Nat Meth Supp/ 2011, 8(Suppl 4):S36-S40.

22. Cahan P, Daley GQ: Origins and implications of pluripotent stem cell variability and heterogeneity. Nat Rev Mol Cell Biol 2013, 14:357-368.

23. Kuchina A, Espinar L, Garcia-Ojalvo J, Suel GM: Reversible and noisy progression towards a commitment point enables adaptable and reliable cellular decision-making. PLoS Comput Biol 2011, 7:e1002273.

24. Ebben JD, Zorniak M, Clark PA, Kuo JS: Introduction to induced pluripotent stem cells: advancing the potential for personalized medicine. World Neurosurg 2011, 76(Suppl 3-4):270-275.

25. Science Daily. [http://www.sciencedaily.com/releases/2012/11/121126151021.htm]

26. Komarova S, Roth J, Alvarez R, Curiel DT, Pereboeva L: Research targeting of mesenchymal stem cells to ovarian tumors via an artificial receptor. J of Ovarian Res 2010, 3:12.

27. Ansboro S, Greiser U, Barry F, Murphy M: Strategies for improvement of therapeutic cells: implications for tissue repair. Eur Cells Mater 2012, 23:310-319

28. Kean TJ, Duesler L, Young RG, Dadabayev A, Olenyik A, Penn M, Wagner J, Fink DJ, Caplan Al, Dennis JE: Development of a peptide-targeted, myocardial ischemia-homing, mesenchymal stem cell. J Drug Target 2012, 20(Suppl 1):23-32.

29. Resina S, Prevot $P$, Thierry AR: Physico-chemical characteristics of lipoplexes influence cell uptake mechanisms and transfection efficacy. PLoS One 2009, 4(Suppl 6):e6058.

30. Kirpotin D, Park JW, Hong K, Zalipsky S, Li WL, Carter P, Benz CC, Papahadjopoulos D: Sterically stabilized anti-HER2 immunoliposomes: design and targeting to human breast cancer cells in vitro. Biochem 1997, 7:36(1):66-75.

31. Gomez-Manzano C, Jiang H, Alonso M, Yung WK, Fueyo J: Gene therapy. Handb Clin Neurol 2012, 104:331-338.

32. Burks SR, Ziadloo A, Kim SJ, Nguyen BA, Frank JA: Noninvasive pulsed focused ultrasound allows spatiotemporal control of targeted homing for multiple stem cell types in murine skeletal muscle and the magnitude of cell homing can be increased through repeated applications. Stem Cells 2013, 31(Suppl 11):2551-2560.

33. Laflamme MA, Zbinden S, Epstein SE, Murry CE: Cell-based therapy for myocardial ischemia and infarction: pathophysiological mechanisms. Annu Rev Pathol 2007, 2:307-339.

34. Vaneycken I, D'huyvetter M, Hernot S, De Vos J, Xavier C, Devoogdt N, Caveliers V, Lahoutte T: Immuno-imaging using nanobodies. Curr Opin Biotech 2011, 22:877-881

35. Sarkar D, Spencer A, Phillips JA, Zhao W, Schafer S, Spelke DP, Mortensen LJ, Ruiz JP, Vemula PK, Sridharan R, Kumar S, Karnik R, Lin CP, Karp JM: Engineered cell homing. Blood 2011, 118:e184-e191.

36. Smart N, Riley PR: The stem cell movement. Circul Res 2008, 102:1155-1168.

37. Zhang JJ: Mechanisms of cell therapy for clinical investigations. an urgent need for large-animal models. Circul 2013, 128:92-94.

38. Gnecchi M, Zhang Z, Ni A, Dzau VJ: Paracrine mechanisms in adult stem cell signaling and therapy. Circul Res 2008, 103:1204-1219.

39. Meirelles LDS, Fontes AM, Covas DT, Caplan Al: Mechanisms involved in the therapeutic properties of mesenchymal stem cells. Cytokine Growth Factor Rev 2009, 20:419-427.

40. Drukker M, Tang C, Ardehali R, Rinkevich Y, Seita J, Lee AS, Mosley AR, Weissman IL, Soen $Y$ : Isolation of primitive endoderm, mesoderm, vascular endothelial and trophoblast progenitors from human pluripotent stem cells. Nat Biotech 2012, 30(Suppl 6):531-544

41. Wolff SN: Second hematopoietic stem cell transplantation for the treatment of graft failure, graft rejection or relapse after allogeneic transplantation. Bone Marrow Transpl 2002, 29:545-552.

42. Zakrzewski JL: Graft failure in allogeneic haematopoietic stem cell transplantation for non-malignant disorders: basics and perspectives. Comp Clin Path 2003, 12(Suppl 1):57-59.

43. Mattsson J, Ringdén O, Storb R: Graft failure after allogeneic hematopoietic cell transplantation. Biol Blood Marrow Transplant 2008, 4(Suppl 1):165-170.

44. Olsson R, Remberger M, Schaffer M, Berggren DM, Svahn BM, Mattsson J, Ringden O: Graft failure in the modern era of allogeneic hematopoietic SCT. Bone Marrow Transp/ 2013, 48(Suppl 4):616.
45. Locatelli F, Lucarelli B, Merli P: Current and future approaches to treat graft failure after allogeneic hematopoietic stem cell transplantation. Expert Opin Pharmacother 2014, 15(Suppl 1):23-36.

46. Sanz-Ruiz R, Ibanes EG, Arrranz AV, Santos MEF, Fernandez PLS, FernandezAviles F: Phases I-III clinical trials using adult stem cells. Stem cells Intern 2010, 1-12.

47. Tara M, Herrick RPM: Tapping the potential of fixed-dose combinations. Nat Rev Drug Disc 2007, 6:513-514.

48. Mocanu MM, Yellon DM: PTEN, the Achilles' heel of myocardial ischemia/ reperfusion injury? Br J Pharmacol 2007, 150:833-838.

49. Ye Y, Lin Y, Atar S, Huang MH, Perez-Polo JR, Uretsky BF, Birnbaum Y: Myocardial protection by pioglitazone, atorvastatin, and their combination: mechanisms and possible interactions. Am J Physiol Heart Circ Physiol 2006, 291:1158-1169.

50. Rosanio S, Ye Y, Atar S, Rahman AM, Freeberg SY, Huang MH, Barry FU, Yochai Birnbaum MD: Enhanced cardioprotection against ischemiareperfusion injury with combining sildenafil with lowdose atorvastatin. Cardiovasc Drugs Ther 2006, 20:27-36.

51. Foubert P, Matrone G, Souttou B, Lere'-De'An C, Barateau V, Plouet J, Le Ricousse-Roussanne S, Levy BI, Silvestre J, Tobelem G: Coadministration of endothelial and smooth muscle progenitor cells enhances the efficiency of proangiogenic cell-based therapy. Circ Res 2008, 103:751-760.

52. Yamahara K, Sone M, Itoh H, Yamashita JK, Yurugi-Kobayashi T, Homma K, Chao T, Miyashita K, Park K, Oyamada N, Sawada N, Taura D, Fukunaga Y, Tamura N, Nakao K: Augmentation of neovascularizaiton in hindlimb ischemia by combined transplantation of human embryonic stem cells-derived endothelial and mural cells. PLoS One 2008, 3:e1666.

53. Kanathezhath B, Walters MC: Umbilical cord blood transplantation for thalassemia major. Hematol Oncol Clin North Am 2010, 24:1165-1177.

54. Madureira AB, Eapen M, Locatelli F, Teira P, Zhang MJ, Davies SM, Picardi A, Woolfrey A, Chan KW, Socie G, Vora A, Bertrand Y, Sales-Bonfim CM, Gluckman $E$, Niemeyer $C$, Rocha $V$ : Analysis of risk factors influencing outcome in children with myelodysplastic syndrome after unrelated cord blood transplantation. Leukemia 2011, 25:449-454

55. Majhail NS, Brunstein CG, Shanley R, Sandhu K, McClune B, Oran B, Warlick $E D$, Wagner JE, Weisdorf DJ: Reduced-intensity hematopoietic cell transplantation in older patients with AML/MDS: Umbilical cord blood is a feasible option for patients without HLA-matched sibling donors. Bone Marrow Transplan 2012, 47:494-498.

56. Oran B, Wagner JE, DeFor TE, Weisdorf DJ, Brunstein CG: Effect of conditioning regimen intensity on acute myeloid leukemia outcomes after umbilical cord blood transplantation. Biol Blood Marrow Transplan 2011, 17:1327-1334.

57. Carrancio S, Romo C, Ramos T, Lopez-Holgado N, Muntion S, Prins HJ, Martens AC, Brinon JG, Miguel JFS, del Canizo MC, Sanchez-Guijo F: Effects of MSC coadministration and route of delivery on cord blood hematopiectic stem cell engraftment. Cell Transplan 2013, 22:1171-1183.

58. Kirpatovskii VI, Kazachenko V, Yanenko EK, Kovalenko EA, Golovanov SA: Enhancement of the anti-ischemic kidney resistance by adaptive hypoxic preconditioning and drug therapy. Bullet Exp Biol Med 1999, 127:278-281.

59. Kato $\mathrm{T}$, Yoshimoto $\mathrm{N}$ : Ischemic preconditioning and outcomes after angioplasty: effects of drug therapy. Drugs 2003, 63:133-138.

60. Diaz Z, Assaraf MI, Miller WHJ, Schipper HM: Astroglial cytoprotection by erythropoietinpre-conditioning: implications for ischemic and degenerative CNS disorders. J Neurochem 2005, 93:392-402.

61. Gidday JM: Pharmacologic preconditioning: translating the promise. Trans/ Stroke Res 2010, 1:19-30.

62. Mersmann J, Berkels R, Zacharowski P, Tran N, Koch A, lekushi K, Dimmeler S, Granja TF, Boehm O, Claycomb WC, Zacharowski K: Preconditioning by toll-like receptor 2 agonist pam3CSK4 reduces CXCL1-dependent leukocyte recruitment in murine myocardial ischemia/reperfusion injury. Crit Care Med 2010, 38:903-909.

63. McNally SJ, Harrison EM, Wigmore SJ: Ethical considerations in the application of preconditioning to solid organ transplantation. J Med Ethics 2005, 31:631-634.

64. Haider HK, Ashraf M: Preconditioning and stem cell survival. J CardiovasC Trans/ Res 2010, 3:89-102.

65. Cai H, Zhang Z, Yang GY: Preconditioned Stem Cells: a Promising Strategy for Cell-Based Ischemic Stroke Therapy. Curr Drug Targets 2014, 15(8):771-779. 
66. Zhou H, Wu S, Joo JY, Zhu S, Han DW, Lin T, Trauger S, Bien G, Yao S, Zhu Y, Siuzdak G, Schöler HR, Duan L, Ding S: Generation of induced pluripotent stem cells using recombinant proteins. Cell Stem Cell 2009, 4(Suppl 6):581.

67. Moschidou D, Mukherjee S, Blundell MP, Drews K, Jones GN, Abdulrazzak H, Nowakowska B, Phoolchund A, Lay K, Ramasamy TS, Cananzi M, Nettersheim D, Sullivan M, Frost J, Moore G, Vermeesch JR, Fisk NM, Thrasher AJ, Atala A, Adjaye J, Schorle H, Coppi PD, Guillot PV: Valproic acid confers functional pluripotency to human amniotic fluid stem cells in a transgene-free approach. Mol Therapy 2012, 20(10):1953-1967.

68. Haider $\mathrm{KH}$, Ashraf M: Preconditioning approach in stem cell therapy for the treatment of infarcted heart. Prog Mol Biol Trans/ Sci 2012, 111:323-356.

69. Watanabe K, Ueno M, Kamiya D, Nishiyama A, Matsumura M, Wataya T, Takahashi JB, Nishikawa S, Nishikawa S, Muguruma K, Sasai Y: A ROCK inhibitor permits survival of dissociated human embryonic stem cells. Nat Biotech 2007, 25:681-686

70. Ramasamy TS, Yu JSL, Selden C, Hodgson H, Cui W: Application of threedimensional culture conditions to human embryonic stem cell-derived definitive endoderm cells enhances hepatocyte differentiation and functionality. Tissue Eng Part A 2013, 19(Suppl 3-4):360-367.

71. Jeremy LH, Yue W, Abarbanell MA, Brent RW, Jiangning T, Daniel RM: Preconditioning mesenchymal stem cells with transforming growth factor-alpha improves mesenchymal stem cell mediated cardioprotection. Shock 2010, 33:24-30.

72. Hu X, Yu SP, Fraser JL, Lu Z, Ogle ME, Wang J, Wei L: Transplantation of hypoxia-preconditioned mesenchymal stem cells improves infarcted heart function via enhanced survival of implanted cells and angiogenesis. J Thorac Cardiovasc Surg 2008, 135:799-808.

73. Pasha Z, Wang Y, Sheikh R, Zhang D, Tiemin Zhao T, Ashraf M: Preconditioning enhances cell survival and differentiation of stem cells during transplantation in infarcted myocardium. Cardiovasc Res 2008, 77:134-142.

74. Carriere A, Ebrahimian TG, Dehez S, Auge N, Joffre C, Andre M, Arnal S, Duriez M, Barreau C, Arnaud E, Fernandez Y, Planat-Benard V, Lévy B, Pénicaud L, Silvestre JS, Casteilla L: Preconditioning by mitochondrial reactive oxygen species improves the proangiogenic potential of adipose-derived cells-based therapy. Arterioscler Thromb Vasc Biol 2009, 29:1093-1099

75. Wisel S, Khan M, Kuppusamy ML, Mohan IK, Chacko SM, Rivera BK, Sun BC, Hideg K, Kuppusamy P: Pharmacological preconditioning of mesenchymal stem cells with trimetazidine (1-[2,3,4-Trimethoxybenzyl]piperazine) protects hypoxic cells against oxidative stress and enhances recovery of myocardial function in infarcted heart through $\mathrm{BCl}-2$ expression. $J$ Pharmacolo Exp Ther 2009, 329:543-550.

76. Stephan MT, Moon JJ, Um SH, Bershteyn A, Irvine DJ: Therapeutic cell engineering using surface-conjugated synthetic nanoparticles. Nat Med 2010, 16:1035-1041.

77. Mamidi MK, Pal R, Govindasamy V, Zakaria Z, Bhonde R: Treat the graft to improve the regeneration ability of the host. Med Hyp 2011, 76:599-601.

78. Yu SP, Wei Z, Wei L: Preconditioning strategy in stem cell transplantation therapy. Trans/ Stroke Res 2013, 4:76-88.

79. Kim SW, Kim HW, Huang W, Okada M, Welge JA, Wang Y, Ashraf M: Cardiac stem cells with electrical stimulation improve ischaemic heart function through regulation of connective tissue growth factor and miR-378. Cardiovascular Res 2013, 100(Suppl 2):241-251.

80. Jaderstad J, Brismar H, Herlenius E: Hypoxia preconditioning increases gap-junctional graft and host communication. Neuro-report 2010, 21:1126-1132

81. Lau TT, Wang DA: Stromal cell-derived factor-1 (SDF-1): homing factor for engineered regenerative medicine. Expert Opin Biol Ther 2011, 11(Suppl 2):189-197.

82. Jones J, Marian D, Weich E, Engl T, Wedel S, Relia B, Jonas D, Blaheta RA: CXCR4 chemokine receptor engagement modifies integrin dependent adhesion of renal carcinoma cells. Exp Cell Res 2007, 313(Suppl 19):4051-4065.

83. Jenkins AJ, Cone EJ: Pharmacokinetics: drug absorption, distribution and elimination. In Drug Abuse Handbook. Edited by Karch SB. CRC Press: Boca Rato'n, FL; 1998:151-201.

84. Brunskill SJ, Hyde CJ, Doree CJ, Suzanne M, Watt SM, Martin-Rendon E: Route of delivery and baseline left ventricular ejection fraction, key factors of bone-marrowderived cell therapy for ischaemic heart disease. Europ J Heart Fail 2009, 11:887-896.
85. Zonta S, De Martino M, Bedino G, Piotti G, Rampino T, Gregorini M, Frassoni F, Dal Canton A, Dionigi P, Alessiani M: Which is the most suitable and effective route of administration for mesenchymal stem cell-based immunomodulation therapy in experimental kidney transplantation: endovenous or arterial? Transplant Proc 2010, 42:1336-1340.

86. Fernandez-Aviles F, San Roman JA, Garcia-Frade J, Fernandez ME, Penarrubia MJ, de laFuente L, Gómez-Bueno M, Cantalapiedra A, Fernández J, Gutierrez O, Sánchez PL, Hernández C, Sanz R, García-Sancho J, Sánchez A: Experimental and clinical regenerative capability of human bone marrow cells after myocardial infarction. Circ Res 2004, 95:742-748.

87. Ott HC, McCue J, Taylor DA: Cell-based cardiovascular repair-the hurdles and the opportunities. Basic Res Cardiol 2005, 100:504-517.

88. Fuchs S, Kornowski R, Weisz G, Satler LF, Smits PC, Okubagzi P, Baffour R, Aggarwal A, Weissman NJ, Cerqueira M, Waksman R, Serrruys P, Battler A Moses JW, Leon MB, Epstein SE: Safety and feasibility of transendocardial autologous bone marrow cell transplantation in patients with advanced heart disease. Am J Cardiol 2006, 97:823-829.

89. Sherman W, Martens TP, Viles-Gonzalez JF, Siminiak T: Catheterbased delivery of cells to the heart. Nat Clin Pract 2006, 3:S57-S64.

90. Dimmeler S, Burchfield J, Zeiher AM: Cell-based therapy of myocardial infarction. Arterioscler Thromb Vasc Biol 2008, 28:208-216.

91. Willing E, Garbuzova-Davis S, Sanberg PR, Saporta S: Routes of stem cell administration in the adult rodent. Methods Mol Biol 2008, 438:383-401.

92. Cindy TJ, Velthoven V, kaVelaars A, van Bel F, Heijnen CJ: Nasal administration of stem cells: a promising novel route to treat neonatal ischemic brain damage. Pediatr Res 2010, 68:419-422.

93. Li Y, Chen J, Chen XG, Wang L, Gautam SC, Xu YX, Katakowski M, Zhang LJ, Lu M, Janakiraman N, Chopp M: Human marrow stromal cell therapy for stroke in rat: neurotrophins and functional recovery. Neurology 2002, 59:514-523.

94. Sykova E, Homola A, Mazanec R, Lachmann H, Konradova SL, Kobylka P, Pádr R, Neuwirth J, Komrska V, Vávra V, Stulík J, Bojar M: Autologous bone marrow transplantation in patients with sub acute and chronic spinal cord injury. Cell Transplant 2006, 15:675-687.

95. Paul C, Samdani AF, Betz RR, Fischer I, Birgit Neuhuber B: Grafting of human bone marrow stromal cells into spinal cord injury: A comparison of delivery methods. Spine (Phila Pa 1976) 2009, 34:328-334.

96. Strauer BE, Brehm M, Zeus T, Kostering M, Hernandez A, Sorg RV, Kogler G, Wernet $P$ : Repair of infarcted myocardium by autologous intracoronary mononuclear bone marrow cell transplantation in humans. Circulation 2002, 106:1913-1918.

97. Moscoso I, Barallobre J, de llarduya ÓM, Añón P, Fraga M, Calviño R, Aldama $\mathrm{G}$, Doménech N: Analysis of different routes of administration of heterologous 5-Azacytidine-treated mesenchymal stem cells in a porcine model of myocardial infarction. Transplant Proc 2009, 41:2273-2275.

98. Rigol MR, Solanes N, Farre J, Roura S, Roque M, Berruezo A, Bellera N, Novensà L, Tamborero D, Prat-Vidal C, Huzman MA, Batlle M, Hoefsloot M, Sitges M, Ramírez J, Dantas AP, Merino A, Sanz G, Brugada J, Bayés-Genís A, Heras M: Effects of adipose tissue-derived stem cell therapy after myocardial infarction: impact of the route of administration. J Card Fail 2010, 16:357-366.

99. Seo SH, Kim KS, Park SH, Suh YS, Kim SJ, Jeun SS, Sung YC: The effects of mesenchymal stem cells injected via different routes on modified IL-12mediated antitumor activity. Gene Ther 2011, 18:488-495.

100. Geffner LF, Santacruz P, Izurieta M, Flor L, Maldonado B, Auad AH, Montenegro X, Gonzalez R, Silva F: Administration of autologous bone marrow stem cells into spinal cord injury patients via multiple routes is safe and improves their quality of life: comprehensive case studies. Cell Transplant 2008, 17:1277-1293.

101. Strauer BE, Kornowski R: Stem cell therapy in perspective. Circulation 2003, 107:929-934.

102. Johanson CE, Uhlenhuth EH: Drug preferences in humans. Fed Proc 1982, 41:228-233.

103. de wit $H$, Uhlenhuth $E H$, Johanson $C E$ : Individual differences in the reinforcing and subjective effects of amphetamine and diazepam. Drug Alcohol Depend 1986, 16:341-360.

104. Thurmann PA: Gender-related differences in pharmacokinetics and pharmocodynamics. Bundesgesundheitsblatt Gesundheitsforschung Gesundheitsschutz 2005, 48:536-540.

105. Soldin OP, Mattison DR: Sex differnces in pharmacokinetics and pharmocodynamics. Clin Pharmocokinet 2009, 48:143-157. 
106. Hughes DA, Aronson JK: A systematic review and empirical analysis of the relation between dose and duration of drug action. J Clin Pharmacol 2010, 50:17-26.

107. Varrassi G, Marinangeli F, Agro F, Aloe L, De Nicola A, Giunta F, Ischia S, Ballabio M, Stefanini S: A double-blinded evaluation of propacetamol versus ketorolac in combination with patient controlled analgesia morphine: analgesic efficacy and tolerability after gynecologic surgery. Anesth Analg 1999, 88:611-616.

108. Struys MMRF, Sahinovic M, Lichtenbelt BJ, Vereecke HEM, Absalom AR: Optimizing intravenous drug administration by applying pharmacokinetic/ pharmacodynamic concepts. Brit J Anaesth 2011, 107:1-10.

109. Bartmann C, Rohde E, Schallmoser K, Pürstner P, Lanzer G, Linkesch W, Strunk D: Two steps to functional mesenchymal stromal cells for clinical application. Transfusion 2007, 47:1426-1435.

110. Yamout B, Hourani R, Salti H, Barada W, El-Hajj T, Al-Kutoubi A, Herlopian A, Baz EK, Mahfouz R, Khalil-Hamdan R, Kreidieh NM, El-Sabban M, Bazarbachi A: Bone marrow mesenchymal stem cell transplantation in patients with multiple sclerosis: A pilot study. J Neuroimmunol 2010, 227:185-189.

111. Kishk NA, Gabr H, Hamdy S, Afifi L, Abokresha N, Mahmoud H, Wafaie A, Bilal D: Case control series of intrathecal autologous bone marrow mesenchymal stem cell therapy for chronic spinal cord injury. Neurorehabil Neural Repair 2010, 24:702-708.

112. Liang J, Zhang H, Hua B, Wang H, Lu L, Shi S, Hou Y, Zeng X, Gilkeson GS, Sun L; Allogenic mesenchymal stem cells transplantation in refractory systemic lupus erythematosus: a pilot clinical study. Ann Rheum Dis 2010, 69:1423-1429.

113. Hare JM, Traverse JH, Henry TD, Dib N, Strumpf RK, Schulman SP, Gerstenblith G, DeMaria AN, Denktas AE, Gammon RS, Hermiller JB, Reisman MA, Schaer GL, Sherman W: A Randomized, Double-Blind, PlaceboControlled, Dose-Escalation Study of Intravenous Adult Human Mesenchymal Stem Cells (Prochymal) After Acute Myocardial Infarction. J Am Coll Cardiol 2009, 54(24):2277-2286.

114. Hare JM, Fishman JE, Gerstenblith G, DiFede Velazquez DL, Zambrano JP, Suncion $\mathrm{V}$, Tracy $M$, Ghersin $E$, Johnston PV, Brinker JA, Breton $E$, Davis-Sproul J, Schulman IH, Brynes J, Mendizabal AM, Lowery MH, Rouy D, Altman P, Wong Po Foo C, Ruiz P, Amador A, Da Silva J, McNiece IK, Heldman AW, George R, Lardo A: Comparison of allogeneic vs autologous bone marrow-derived mesenchymal stem cells delivered by transendocardial injection in patients with ischemic cardiomyopathy: the POSEIDON randomized trial. JAMA 2012, 308:2369-2379.

115. Geber J: Meeting coverage "ALS Stem Cell Therapy: Too Soon to Tell". [http://www.medpagetoday.com/MeetingCoverage/ANA/42288]

116. Clinical Trials of U.S. National Institutes of Health. [http://clinicaltrials.gov/ show/NCT01609283]

117. Hess DC, Sila CA, Furlan AJ, Wechsler LR, Switzer JA, Mays RW: A doubleblind placebo- controlled clinical evaluation of MultiStem for the treatment of ischemic stroke. Int J Stroke 2014, 9(3):381-386.

118. Clinical Trials of U.S. National Institutes of Health. [http://clinicaltrials.gov/ ct2/show/NCT01144962]

119. Mason C, Mason J, Culme-Seymour EJ, Bonfiglio GA, Reeve BC: Cell Therapy Companies Make Strong Progress from October 2012 to March 2013 Amid Mixed Stock Market Sentiment. Cell Stem Cell 2013, 12:644-647.

120. Ma T: Mesenchymal stem cells; cell therapy; cell expansion and processing. World J of Stem Cells 2010, 2:13-17.

121. Ledford KJ, Zeigler F, Bartel RL: Ixmyelocel-T, an expanded multicellular therapy, contains a unique population of M2-like macrophages. Stem Cell Res Ther 2013, 4:134

122. Schwartz SD, Hubschman JP, Heilwell G, Franco-Cardenas V, Pan CK, Ostrick RM, Mickunas E, Gay R, Klimanskaya I, Lanza R: Embryonic stem cell trials for macular degeneration: a preliminary report. Lancet 2012, 379(9817):713-720

123. Vaes B, Van't Hof W, Deans RJ, Pinxteren J: Application of MultiStem allogeneic cells for immunomodulatory therapy: clinical progress and pre-clinical challenges in prophylaxis for graft versus host disease. Front Immunol 2012, 3:345.

124. BioTime. [http://www.biotimeinc.com/]

125. Cytomedix regenerative therapies. [http://www.cytomedix.com/]

126. Cytori. [http://www.cytori.com/Home.aspx]

127. Kantoff PW, Higano CS, Shore ND, Berger ER, Small EJ, Penson DF, Redfern CH, Ferrari AC, Dreicer R, Sims RB, Xu Y, Frohlich MW, Schellhammer PF: Sipuleucel-T Immunotherapy for Castration-Resistant Prostate Cancer. N Engl J Med 2010, 363:411-422.
128. Fibrocell Science. [http://www.fibrocellscience.com/about/about-fibrocell/]

129. Immunocellular Therapeutics. [http://www.imuc.com/technology]

130. J-TEC Japan Tissue Engineering. [http://www.jpte.co.jp/english/business/ Regenerative/index.html]

131. Medipost. [http://www.medi-post.com/am_1.asp]

132. Mesoblast: The regenerative medicine company. [http://www.mesoblast com/about-us/company-overview]

133. Neostem. [http://www.neostem.com/about/overview/]

134. Neuralstem Cell therapy. [http://www.neuralstem.com/cell-therapy]

135. Northwest Biotherapeutics. [http://www.nwbio.com/]

136. Osiris. [http://www.osiris.com/biosurgery.php]

137. Pharmicell. [http://www.pharmicell.com/eng/index.asp]

138. Pluristem Therapeutics. [http://www.pluristem.com/index.php/about2.html]

139. Stem Cells. [http://www.stemcellsinc.com/About-Us/Overview.htm]

140. Tigenix. [http://www.tigenix.com/en/page/4/company]

141. Murphy MB, Moncivais K, Caplan Al: Mesenchymal stem cells: environmentally responsive therapeutics for regenerative medicine. Exp Mol Med 2013, 45(e54):1-16.

142. Haack-Sørensen M, Friis T, Mathiasen AB, Jørgensen E, Hansen L, Dickmeiss E, Ekblond A, Kastrup J: Direct intramyocardial mesenchymal stromal cell injections in patients with severe refractory angina: one-year follow-up. Cell Transplant 2013, 22:521-528.

143. Chen L, Tredget EE, Wu PYG, Wu Y: Paracrine factors of mesenchymal stem cells recruit macrophages and endothelial lineage cells and enhance wound healing. PLOS One 2008, 3:e1886.

144. Falanga V, Iwamoto S, Chartier M, Yufit T, Butmarc J, Kouttab N, Shrayer D, Carson P: Autologous bone marrow-derived cultured mesenchymal stem cells delivered in a fibrin spray accelerate healing in murine and human cutaneous wounds. Tissue Eng 2007, 13:1299-1312.

145. Bey E, Prat M, Duhamel P, Benderitter M, Brachet M, Trompier F, Battaglini $P$, Ernoul I, Boutin L, Gourven M, Tissedre F, Crea S, Mansour CA, de Revel T, Carsin H, Gourmelon P, Lataillade JJ: Emerging therapy for improving wound repair of severe radiation burns using local bone marrow-derived stem cell administrations. Wound Repair Regen 2010, 18:50-58.

146. Araki R, Uda M, Hoki Y, Sunayama M, Nakamura M, Ando S, Sugiura M, Ideno $H$, Shimada A, Nifuji A, Abe M: Negligible immunogenicity of terminally differentiated cells derived from induced pluripotent or embryonic stem cells. Nature 2014, 494:100-105.

147. Charron D: Allogenicity \& immunogenicity in regenerative stem cell therapy. Indian J Med Res 2013, 138:749-754.

148. Abbasalizadeh S, Baharvand $H$ : Technological progress and challenges towards CGMP manufacturing of human pluripotent stem cells based therapeutic products for allogeneic and autologous cell therapies. Biotech Adv 2013, 31(8):1600-1623.

149. Ma Q, Lu AYH: Pharmacogenetics, Pharmacogenomics, and Individualized Medicine. Pharmacol Rev 2011, 63:437-459.

doi:10.1186/s12967-014-0243-9

Cite this article as: Srijaya et al:: Advancing stem cell therapy from bench to bedside: lessons from drug therapies. Journal of Translational Medicine 2014 12:243.

\section{Submit your next manuscript to BioMed Central and take full advantage of:}

- Convenient online submission

- Thorough peer review

- No space constraints or color figure charges

- Immediate publication on acceptance

- Inclusion in PubMed, CAS, Scopus and Google Scholar

- Research which is freely available for redistribution 